\title{
Mentoring as professional development intervention for mathematics teachers: A South African perspective
}

\begin{tabular}{|c|c|}
\hline \multicolumn{2}{|c|}{$\begin{array}{l}\text { Authors: } \\
\text { Benita Nel } \\
\text { Kakoma Luneta }^{1,2}\end{array}$} \\
\hline \multicolumn{2}{|c|}{$\begin{array}{l}{ }^{1} \text { Mathematics Education } \\
\text { Department, University of } \\
\text { South Africa, South Africa }\end{array}$} \\
\hline \multicolumn{2}{|c|}{$\begin{array}{l}{ }^{2} \text { School of Education, } \\
\text { University of the } \\
\text { Witwatersrand, South Africa }\end{array}$} \\
\hline \multicolumn{2}{|c|}{$\begin{array}{l}{ }^{3} \text { Faculty of Education, } \\
\text { University of Johannesburg, } \\
\text { South Africa }\end{array}$} \\
\hline \multicolumn{2}{|c|}{$\begin{array}{l}\text { Corresponding author: } \\
\text { Benita Nel, } \\
\text { benita.nel@wits.ac.za }\end{array}$} \\
\hline $\begin{array}{l}\text { Dates: } \\
\text { Received: } 09 \text { J } \\
\text { Accepted: } 19 \\
\text { Published: } 22\end{array}$ & $\begin{array}{l}\text { une } 2016 \\
\text { une } 2017 \\
\text { Sept. } 2017\end{array}$ \\
\hline \multicolumn{2}{|c|}{$\begin{array}{l}\text { How to cite this article: } \\
\text { Nel, B., \& Luneta, K. (2017). } \\
\text { Mentoring as professional } \\
\text { development intervention } \\
\text { for mathematics teachers: } \\
\text { A South African perspective. } \\
\text { Pythagoras, 38(1), a343. } \\
\text { https://doi.org/10.4102/ } \\
\text { pythagoras.v38i1.343 }\end{array}$} \\
\hline \multicolumn{2}{|c|}{$\begin{array}{l}\text { Copyright: } \\
\text { (C) 2017. The Authors. } \\
\text { Licensee: AOSIS. This work } \\
\text { is licensed under the } \\
\text { Creative Commons } \\
\text { Attribution License. }\end{array}$} \\
\hline \multicolumn{2}{|l|}{ Read online: } \\
\hline 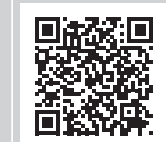 & $\begin{array}{l}\text { Scan this QR } \\
\text { code with your } \\
\text { smart phone or } \\
\text { mobile device } \\
\text { to read online. }\end{array}$ \\
\hline
\end{tabular}

Only a small percentage of mathematics teacher professional development activities in South Africa include pedagogy and instruction approaches required to teach the content. In the light of the poor mathematics results, it is of pertinent importance that teachers need to be developed in terms of the mathematics they teach and the pedagogical component of it. A teachers' professional development programme that used mentoring as one of the interventions was investigated where the mentor conducted classroom observations and had post-observation conferences with the teachers. The data from the observations, post observation conferences and interviews of both the mentors and the mathematics teachers was used to inform the off-site workshops on mathematics content and the instructional skills required to effectively teach the content. Mentoring supported the teachers in terms of mathematics content and instruction, team teaching and lesson preparation. The teachers' individual content and instructional needs were also assessed and supported. The study revealed that mentoring that takes cognisance of teachers' content and instructional needs enhanced their lesson preparation and understanding of mathematics as well as the skills required to teach it effectively. The study recommends mentoring as an effective intervention in professional development programmes especially when it is informed by the teachers' instructional and content needs.

\section{Introduction}

In the South African context, mentoring in professional development programmes has the potential to equip teachers in mediating teaching and learning (Guskey, 2000). In this article, we argue that one key factor in ensuring effective professional development, specifically in terms of pedagogy and instruction, is to invite mentors into the classroom to support teachers to rethink the teaching and learning taking place in order to devise appropriate interventions customised to the needs of teachers. Fundamentally, this means authentic and accurate needs analysis which can direct appropriate interventions, either one-on-one, or in out-of-class workshops, linked to the specific needs of the teachers (Luneta, 2012).

Only a small percentage of teacher professional development initiatives in South Africa include mathematics pedagogy and instruction (Reddy, 2006). It can therefore be concluded that most of the professional development (PD) revolves around content, curriculum and assessment. A concern can then be expressed that most PD initiatives are not focusing on mathematical content and instructional challenges that individual teachers experience in classrooms and it is this shortfall that probably perpetuates the poor content delivery and performance of South African learners in mathematics internationally. The introduction of mentoring, which included on-site classroom support to practising teachers (Sibanda \& Jawahar, 2012), allowed for constructive feedback on how to improve their teaching (Edwards, 1998; Luneta, 2012). This constructive feedback from the mentor should also be supported by a conducive learning environment where effective communication takes place and the mentee is treated as a colleague (Ambrosetti \& Dekkers, 2010). Mentoring as PD with on-site intervention is more effective than interventions detached from the classroom (De Clercq \& Phiri, 2013). Nel (2015) asserts that interventions that are not linked to the classroom and the needs of individual teachers have limited impact on PD that is aimed at teachers' mathematics content knowledge and the instructional skills required to teach the subject effectively.

This article is based on the larger study of Nel (2015) which evaluated a mathematics PD programme initiative which included mentoring as an intervention that was implemented in a 
rural mining district in South Africa. The programme sought to address gaps relating to the teachers' instructional skills as well as some of the mathematics content knowledge that was required. The research question was: How can mentoring as a PD intervention for mathematics teachers in South Africa support teachers in their development?

\section{Literature review}

South Africa is faced with a challenge of redressing inequalities of the past (Graven, 2014) where a significant number of teachers were trained in underdeveloped teacher training colleges of education created by the apartheid government (Gordon, 2009). Although the poor performance of learners in mathematics has been high on South Africa's agenda for some time now (Centre for Development and Enterprise, 2013; Kriek \& Grayson, 2009), no significant improvement has been noted in learners' mathematical knowledge outputs.

The quality of teachers' instruction has a direct impact on their learners' achievements (McKinsey \& Company, 2007; Venkat \& Spaull, 2015), so in teacher PD programmes the emphasis should be on improving the instruction of the individual teacher. However, this cannot be done with a one-size-fits-all approach, as in off-site workshops detached from the classroom. Luneta (2012) points out that inservice teacher education programmes in South Africa predominantly make use of off-site approaches, especially continuous professional development of mathematics teachers. According to De Clercq and Phiri (2013, p. 80), however, often off-site teacher development is 'rarely able to make teachers change paradigm and improve their classroom practice'. Furthermore, the inability of the subject advisors to supervise teachers' performance (De Kadt, 2010) adds to the improbable ability of most PD programme to change teachers' practices. There are also claims that many PD programmes are not geared to 'address the context in which teachers are operating in the classrooms' (Islam, 2012, p. 20). Interventions that are directly linked to the classroom situation as well as the specific needs of the individual should be implemented to ensure effective teacher development and a possible improvement in learner performance, especially in mathematics. Santamaria (2009) asserts that teachers should make instructional decisions that suit their learners' needs. The new curricula introduced in South Africa also required a move away from teacher-centredness to a more learnercentred approach where the teacher acts more as a facilitator in the classroom. The quality of learning can also be enhanced if we improve the interaction between teachers and learners in the classroom (McKinsey \& Company, 2007). Those teachers, referred to earlier, who were trained in the teacher training colleges, were exposed to the use of rigid rotelearning methods of teaching, as well as an educational philosophy and pedagogy that did not encourage learners in the class to critically analyse or raise questions pertaining to the content or the instructions they received (Gardiner, 2008). That style of teaching did not favour spontaneous interaction and relevant communication between teachers and learners in mathematics classrooms. The current move worldwide is to have mathematics classrooms that are informed by teachers that are grounded in the mathematics they teach as well as the instructional skills required to do so (Schoenfeld \& Floden, 2014; Sullivan, 2011). Teachers with such skills would exhibit Kilpatrick, Swafford and Findell's (2001) five desirable strands of good mathematics teachers and learners', Schoenfeld and Floden's (2014) framework of Teaching for Robust Understanding in Mathematics (TRU Math) and Stein, Engle, Smith and Hughes's (2008) five key pedagogical principles model for mathematics effective classrooms.

All of the provinces in South Africa have schools situated in rural areas with their unique conditions and challenges, where teachers work under solitary conditions and without much human support (Gardiner, 2008). The PD programme under investigation was also implemented in a rural setting where a shortage of qualified teachers (Department of Education, 2005; Islam, 2012) was rampant. The situation was particularly severe with regard to qualified mathematics, science and English teachers (Masinire, Maringe \& Nkambule, 2014). These three subject areas are interlinked such that when a learner has a challenge with reading and understanding English as language, it often has a negative effect on understanding mathematics and science. A challenge particularly in rural high schools is the lack of teachers' subject content knowledge (Human Sciences Research Council, 2005) and limited resources also contribute to teachers' low morale (Gordon, 2009). Although workshops are offered by training institutions to teachers in rural areas, the transfer of new ideas into teachers' classroom practice has often been questionable (Gardiner, 2008). In addition, other programmes like mentoring could ensure that what was learnt in PD is transferred and modified to suit classroom practice.

Mentoring refers to a professional relationship in which an experienced person, the mentor, assists another one (the mentee) in developing specific skills and knowledge that will enhance the less experienced person's professional and personal growth (Aspfors \& Fransson, 2015). In this study, the mentor was responsible for a number of mathematics teachers in rural schools which were geographically scattered. We have argued in this research that mentoring is an intervention that can be located in the classroom and be customised to the specific needs of the individual teacher. It entails a relationship between a more experienced person (mentor) and a less experienced individual (mentee) (Shulman \& Sato, 2006) with the intent of growing and developing the mentee (Allen, Finkelstein \& Poteet, 2009). This type of teacher development has the potential of being on site, needs driven and context specific. Such an undertaking could mean that the incorporation of mentoring in a PD programme can be a solution to the generic training of the past. Guskey (2000) agrees that the inclusion of mentoring, pedagogy and instruction in a PD programme increases the potential of yielding better equipped teachers. On-site classroom support yields more significant success than externally imposed expectations (Onchwari \& Keengwe, 2008). 
The mentor can give constructive feedback to the mentee and incorporate team-teaching or co-teaching, and in that way demonstrate other ways of instruction developed through reflective practices after a lesson, as well as have a better approach to interacting with learners (Badiali \& Titus, 2010). Mentoring thus lends itself to the mentee receiving individual attention and support, and the sharing of knowledge as well as experiences (Murray, 2010). Good mentoring provides space for self-reflection within the school itself, a strategy that can boost the teachers' commitments towards their own development (Islam, 2012). Epistemologically mentoring can counteract workshop and seminars that are detached from classrooms and that do not address unique instructional and content needs of individual mathematics teachers (Luneta, 2006).

Possible challenges with mentoring have always been ineffective implementation, a mismatch between the mentor and the mentee, the lack of commitment to the process, and time and financial constraints as well as inappropriate needs analysis (Rhodes, Stokes \& Hampton, 2004). Mentoring is also quite labour-intensive and not easy to roll out on a large scale. It is, however, important to contextualise the engagement. According to Sullivan (2011), current debates on mentorship and professional development in mathematics education are pointing to the recognition of the critical complementarity of the two constructs and that mentorship should and ought to be addressed as professional development.

\section{Context}

This article reports on part of a broader intervention involving mathematics teachers. The mathematics PD programme ran for three years in a particular rural mining district in a province in South Africa. The programme used different interventions, namely workshops and mentoring, coupled with classroom visits and cluster meetings, in the quest to develop the teachers' mathematical competence and performance that addressed gaps within their learners' mathematical knowledge and skills (Khosa, 2010). The topics dealt with in the workshops emanated from the analysis of pre-tests that teachers wrote before the start of the programme, but also through requests from participants as well as classroom observations. The topics included financial mathematics, circle geometry, probability, applications in calculus, exponents, algebraic inequalities, trigonometry and contextualised quadratic number patterns at the Further Education and Training level.

Mentoring is an intervention that supported the workshops by having scheduled one-on-one sessions between the mentors and the teachers after classroom visits and lesson observations. There were two mentors involved in the programme. The first mentor left at the end of the second year and the second mentor then took over for the remaining year. The participants got along well with the first mentor but not with the second one for reasons unknown to the researcher. An interview was done only with the first mentor as the second mentor passed away soon after the programme, hence the mention of one mentor at times and two at other times. In the classroom visits the mentor determined areas where the individual teacher needed support and these were addressed in the workshops or on a one-on-one basis. During classroom visits the mentor at times also co-taught with the teacher. The classroom visits gave the mentor firsthand insight into the classroom conduct and instructional abilities of the teacher and provided an opportunity for a needs assessment per teacher. Workshop topics were then determined from the needs analysis. The cluster meeting did not form part of this study.

The different teachers were given pseudonyms to protect their anonymity. They were allocated the following codes to distinguish between the different participants: MK, NK, RB, SB and SR, and the mentor was allocated AK. MK, SB and SR were heads of the mathematics departments of their schools and the other two teachers were post level one teachers. All of them had very full workloads and were teaching two or even more subjects at the time. All the schools are rural schools and very far apart in a mining-dominated region in South Africa.

\section{Methodology}

This study followed a qualitative approach where events and people involved in the PD programme were scientifically discussed and where thick and rich descriptive data were generated without the use of numerical data (Best \& Kahn, 1998). The specific PD programme under investigation is seen as a case study where in-depth understanding of the programme was achieved through intensive data collection. Yin's (1984, p. 23) definition of a case study was used: 'a research method that uses empirical inquiry to investigate a contemporary phenomenon within its real-life context'. In this study, the 'phenomenon' was mentorship and teachers and mentees' real-life contexts. The target population was all the teachers in the Further Education and Training band involved in a mathematics PD programme. The five schools involved in the programme were all situated in a rural setting with mostly one teacher teaching both mathematics and science in the Further Education and Training band at their respective schools. One of the schools' mathematics teachers was not involved in the research as he left the district for another post. At the end, there were five teachers involved in the research as one school had two teachers who took part in the programme. Due to the small number of mathematics participants in the programme, all the Further Education and Training mathematics teachers in the four remaining schools took part in the research.

Primary and secondary data sources were used in the study. The researcher was not the mentor and did lesson observations separate from that of the mentor. The primary data were generated from interviews with the participants and with the mentor teachers using different semi-structured interviews for the teachers and the mentor respectively. Reports written by the mentor after every school visit, lesson observation reports done by the mentor, workshop reports, the project 
proposal and the programme executive manager's reports (secondary data sources) were among the many data sources. The lesson observation schedule that the researcher compiled and used during class visits (primary data source) was also used as a data source. The different components of the observation schedule included aspects like whether learners were involved in active learning, the way in which the teacher facilitated learning, the type of support given to learners, the correctness of teacher's content knowledge, whether lesson plans were done and whether the teacher was on schedule in terms of the year programme.

The semi-structured, open-ended, face-to-face interviews were used with both the teachers as well as the mentor. All the teachers were asked the same questions on the same topics to make comparisons between the interviews possible (Best \& Kahn, 1998). In order to elicit the teachers' different perspectives, the open-ended interviews assisted in making these interviews flexible to probe into comments made (Hatch, 2002). The interview questions included questions on whether and how they felt they developed as teachers in terms of preparing and conducting lessons, their assessment skills, timeous completion of the syllabus, the role of the mentor and recommendation on how to improve PD programmes.

In the compiling of the interview schedules as well as during the data analysis phase, the researcher used a thematic approach to then draft the questions as well as structure the data analysis. The thematic approach, a qualitative data reduction process (Grbich, 2006), was used to analyse data. Here related data segments were grouped or consolidated around a central concept or category, which can also be referred to as codes. These predetermined categories were derived from the literature review pertaining to effective PD programmes as well as using the programme under investigation's aims and objectives. The following predetermined categories were used to analyse the data: support through lesson observations, completion of syllabus, teachers' written lesson preparations, how teachers supported learners in class and learner participation, and homework given to learners. Analysis of the mentor reports was also done by using the inductive approach using the same categories as stated earlier. These different data sources provided rich data and aided in data triangulation (Krefting, 1991) and added to the trustworthiness of the study (Babbie \& Mouton, 2001; Lietz, Langer \& Furman, 2006).

\section{Ethical considerations}

Ethical clearance was obtained from the provincial Department of Education as well as the university through which the qualification was done (Reference: 2013/ISTE/30). Thereafter, consent was sought from the schools, participating teachers as well as the learners involved. The researcher explained the aims and objectives of the study to the participants and assured them that their participation is voluntary. Before signing the consent forms, the participants were also informed that they can withdraw from the study at any time without being penalised in any way and that their identities will be kept anonymous by using pseudonyms in the writing up of the study. They were also informed that confidentiality pertaining to the collected data will be upheld.

\section{Findings and discussion}

The findings are presented according to each classification of the data. We used descriptive analysis (ed. Maree, 2011) which is the transformation of raw data into a form that will make them easy to understand and interpret; rearranging, ordering, and manipulating data to generate descriptive information' (Zikmund, 2003, p. 1). The raw data from the lesson preparation and observations, and the completion of content, the supporting of learning in the classroom, learner participation, lesson preparations and the validity of homework given to the learners were analysed so as to provide thick descriptions of the events (Gall, Gall \& Walter, 1999).

\section{Support through lesson observations}

The mentor assisted the participants of the programme in their development as teachers by observing their lessons followed by feedback and reflection sessions. These sessions were integrated with workshops where developmental issues were interrogated. The lesson observations by the mentor revealed areas where teachers needed support and the mentor assisted them in those areas through one-to-one conversations after the observations, co-teaching and workshops on lesson planning. The participants gave insight in the interviews into how they experienced the sessions where the mentor observed their lessons. Here for instance is an excerpt of the interview with NK:

They came to school, observed the lesson; they even teach. ... It was very nice because there were some of the aspects that I was having a problem with. So ... but after their visit, I was just fine. Even if we go together to the class, I give them [mentors] chance to say something or do something on the board. It was very nice and maybe even with these learners. If they see a different person talking with them, they become better. (Nel, 2015, p. 196)

The interviewee had a positive experience with the mentor observing his lesson and mentioned that co-teaching also took place, an effective method of supporting teachers in their development. Through co-teaching the teachers had the opportunity to see how the mentor taught certain sections and reflected on what methods and strategies could be incorporated in their own teaching. Co-teaching allows the mentor to model good practices to the mentee in their own classroom setting (McLaughlin \& Talbert, 2006). These good practices include different instructional practices which are customised to the mentee within their own classroom setting and which can also reveal to the mentee that these practices are implementable in their rural settings. Co-teaching, unlike ideas given to teachers attending off-site one-size-fits-all workshops detached from the teachers' classroom (De Clercq \& Phiri, 2013), can inspire teachers to try out instructional strategies that they were not used to in the past. One can also gather that the teachers welcomed the input of the mentor in 
the lesson and gave the mentor opportunities to 'say something' or 'do something on the board'. In this instance, the teacher acknowledged that there were areas where he experienced difficulty in his classroom teaching or practice and the mentor's intervention added value to his development. This interview excerpt above also alludes to a possible improvement in the learners' understanding of concepts through the co-teaching. The mentor became part of these classroom interactions and was later not perceived as a stranger by either the teacher or the learners, as stated in an interview with RB:

What I've learnt about mentoring is that for every lesson that you do, there is a correction for it; there is an improvement every lesson. There is no 100\% lesson. There is an improvement for every lesson because someone who is sitting and watching can improve on your lesson. (Nel, 2015, p. 196-197)

This quote reveals that mentoring allows for learning through reflective conversations with the mentor (Badiali \& Titus, 2010), and that the teacher realised that there were areas in the lessons where he could improve. Edwards (1998) highlights the giving of feedback to the mentee as one of the dominant roles of the mentor. In reaction to the feedback, the teacher could reflect on their teaching and rethink possible changes to it. The teacher also indicated that even if one improves one's lesson presentation, there are still aspects in a lesson that can be improved. This quote further confirms Kilpatrick et al.'s (2001) argument that teachers' understanding and the rethinking of their own teaching is a continuous process and improvement is never-ending. Both previous excerpts also reveal that the mentor's input was welcomed by the teachers as the assistance was perceived as helpful. This implies a good match between the teachers and the mentor.

Another participant, SR, mentioned the importance of the feedback after the lesson observation:

She was going with us to the classroom to observe the lessons ... what I can say was it was effective because when we come from the classroom, we sit down and we discuss the shortcomings of the lesson and other things. (Nel, 2015, p. 198)

Feedback is important. This customised feedback has the potential to sustain teacher development as it is linked to the individual needs of teachers (Hattingh, 2009). These regular lesson observations and supportive discussions are some of the pertinent benefits of mentoring (Harrison, 2005). Constructive feedback also assists the teacher to reflect on their practice in class. The teacher's choice of the word 'effective' also indicates that the teacher experienced the classroom observation sessions as beneficial to their growth as a professional. It needs to be remembered that these are all teachers with big workloads (having more than 30 periods per week) and through this PD what is added is a mentor taking up their limited free periods or their lunch breaks to discuss observed lessons with them. Perceiving the input of the mentor in an 'effective', that is positive way, implies that the PD initiative added value to these teachers in addition to the efforts from their side.
However, in the interview with the mentor, on the question as to what could be done to improve the mentoring, AK revealed that she did not always find sufficient time for the feedback session after the lesson observations:

We didn't have a lot of time to sit and talk to them - the teacher after [the lesson observation]. ... I think there should have been more time even if they (the teachers) had to miss a lesson. The right time to talk about a lesson was straight after it. And you need a full period not quickly before they go to the next period. You know it doesn't work. And just more time because you know they're quite far apart - the schools you know. (Nel, 2015, p. 211)

The mentor teachers also observed and recognised the insufficient time for the post observation meetings. The question of time is acknowledged in other studies that assert that the effectiveness of mentoring is often enhanced by the amount of time spent between the mentor and the mentee; however, time constraints are a frequent challenge for mentors and insufficient time can often have an adverse impact on achieving their learning objectives' (Myall, LevettJones \& Lathlean, 2008, p. 1840). The mentor also highlights the importance of reflection sessions immediately after the lesson observation while the detail of the lesson is still fresh in the minds of both the teacher and the mentor. It is also evident from the interviews that enough time should be set aside for the reflection sessions immediately after the lesson so that it can allow for thorough reflection. This ensures that lesson observations as a tool to develop teachers can be used optimally. However, it is also possible that the extensive distance between the rural schools contributed to the lack of time available after the lesson as the mentor had to rush to the next school for other lesson observations. Training of mentor teachers in each school would be the most appropriate solution to the problem.

\section{Completion of syllabus}

It is very important for teachers to complete each grade's syllabus as they are structured and sequenced to support the progression of concepts. It is, however, alarming to find that in South Africa there are instances where the mathematics syllabus is not completed in a given year (Makgato \& Mji, 2006), leaving some topics not covered in certain grades. The mentor reports did not indicate much in this category as teachers in general did not update their files on which sections of the syllabus they had already covered. It should also be noted that schools in rural areas are not necessarily monitored regularly by the district officials due to the remote location of these schools (Adedeji \& Alaniyan, 2011). However, the interviews shed some light on this category. Teacher SR was initially unable to finish the syllabus within the stipulated year, but gained knowledge about new approaches of how to cover the work. This enabled him to complete the syllabus timeously:

It is a problem to finish the work plan because I am having a lot of classes here. ... Ja, after [the programme] chipped in, then I managed to finish everything ... because they just showed us how to teach this topic, the skill of teaching this topic because 
before we were dwelling much, before [the programme] we were dwelling much on the same topic. This took up a lot of time. But now they have just given us the direction that we just do this, concentrate on this and that and that. So that is how we can cover the syllabus. You see those skills are very, very important from those two people [the two mentors]. They just give you the overall plan, how to attack it. (Nel, 2015, p. 184)

What became evident through this interview was that the teacher initially did not manage to complete the syllabus for a particular year. This was due to him spending too much time on a particular topic and eventually running out of time later on in the year. The mentoring then assisted him in pertinent areas within particular topics which he needed to emphasise in class to enable learners to grasp concepts. The mentor assisted him in managing his time in class which led to him completing the syllabus within the required time frames. The mentor who came into his classroom could pick up this challenge of the teacher and could support him in such a way that his classroom practice changed.

Workload also turned out to be an issue as this teacher, besides being the head of department at the school, was also teaching Grades 10, 11 and 12 mathematics in addition to physical science for two other grades. This was alluded to when he mentioned in the excerpt that he had 'a lot of classes'. This teacher had a big teaching load due to the shortage of qualified mathematics teachers at this rural school. So, although this teacher was assisted by the mentoring to complete the syllabus within the required timeframes, I have my reservations if the timeous completion of the syllabus can be sustained if he continues to have this big teaching load.

\section{Teachers' lesson preparation}

Written lesson plans describe what is planned to be covered in the classroom (McKay, 2010). Individual lessons cannot be successful if they are not planned thoroughly as well as integrated into the medium-term and long-term plans (Croft, Coggshall, Dolan, Powers \& Killion, 2010). Therefore, lesson preparation is an important aspect of the teacher's daily practice. At the start of the programme it was evident that the teachers did not develop formal lesson preparations, though reports indicated that some form of preparation was done from the way lessons were conducted. The lessons were written on rough pieces of paper without clearly specified lesson aims and objectives, instructional approaches, learners' activities and lesson evaluation strategies. This was also evident in the excerpt of MK on the question of whether the teachers prepared written lesson plans:

You know the way we used to do some lesson plans ... it's just only things that maybe we think is right to do. But when the project now came in, we [were taught]: for a lesson preparation you must do one, two, three. That is how a lesson plan must look like. (Nel, 2015, p. 175)

This teacher reveals that he did not do lesson preparation according to a prescribed template with detailed sections, but merely according to what he thought was correct.
Through the PD programme he was taught what to include in the lesson preparation. The mentor then followed this up during school visits to guide the teachers on this aspect. SR mentioned:

Before the project I did not have lesson preparation, but now during the project, they showed us how to prepare Mathematics. ... So it's more advisable for any teacher that whenever you go to the class, you must have a lesson, you must have a plan for the particular lesson. (Nel, 2015, p. 181)

This teacher acknowledged that he did not do lesson preparation before the programme was implemented. This was a teacher who was in the profession for quite a number of years. The challenge, however, is the centrality of lesson preparation to teaching and learning where what will be done in the classroom is outlined on a daily basis (McKay, 2010). In daily lesson preparations teachers should outline the methods and strategies used to achieve their learning outcomes (Adedeji \& Alaniyan, 2011). Through the programme he realised that he needed to prepare a lesson plan for every lesson he want to conduct. The training of the teachers in the programme was done after the mentor realised during school visits that teachers did not do formal written out lesson preparations. So the gap was identified by the mentor and support was put into place to address the matter.

Unfortunately this aspect of not doing written lesson preparation was only addressed in the last year of the threeyear programme, leaving very little time for monitoring and refining this practice even more.

\section{How teachers should support learners in class and learner participation in class}

Teachers' key role is the facilitation of learning in the classroom. They therefore need to constructively support learners and ensure active participation in class. Development in these areas was ignited when the following was observed by the mentor during lesson observation of $\mathrm{MK}$, as documented in a mentor report:

On exponents the learner wrote $3,2^{5}$ instead of $3.2^{5}$. (Nel, 2015, p. 123)

The teacher did not notice this, and the mentor alerted him to this. It can be assumed that the teacher did not check what the learners wrote in their books to which the mentor alerted the teacher. In later reports the same teacher's conduct was described as giving learners 'immediate' feedback on classwork activities. This indicates that the teacher had observed the importance of providing feedback soon after the learners have worked through the assessment tasks rather than wait for some days or the following day. This highlights a shift to supporting learners more in class than before through the intervention of the mentor.

MK used group work as a teaching strategy well, although the mentor noticed that it was time consuming. The teacher was advised by the mentor as to how to alleviate the time issue. 
Teachers were advised by the mentor to work out the solutions to classwork exercises beforehand to ensure that they did not get into a situation where they struggled to find solutions to the problems in front of the learners (progress report on $\mathrm{SB})$ :

[We were taught to have] detailed worked out solutions for problems given in class and ... [for] homework. (Nel, 2015, p. 122)

In other mentor reports on MK there were indications that few learners participated in the lessons. However, in later reports it was noted that co-facilitation took place where more learners were involved in the lesson (mentor report on $\mathrm{NK}$ ). This alludes to the mentor demonstrating how learners can be encouraged to participate within the confinement of the teacher's own classroom. The linking of PD initiatives with the teacher's own classroom is important for effective PD (De Clercq \& Phiri, 2013). This approach lends itself to possible customised ways of bettering teaching in the teacher's own classroom, unlike recommending best practices to a group of teachers who are detached from their schools' context.

\section{Homework given to learners}

Mathematics is an application subject where learners need to practise their knowledge of and skills in the different topics to ensure complete mastery. Therefore, classwork should be supplemented with homework exercises to ensure that learners progressively develop their knowledge and skills. This is why investigation was undertaken to establish whether the participants gave learners homework on a regular basis. In the mentor reports of three of the participants, mention was made that they gave homework regularly, but that the other two participants gave homework sporadically. However, there was a challenge with regard to the time taken to go through or correct the homework in the following lessons. One teacher took an entire period to mark the homework, which resulted in this teacher not making sufficient progress with the syllabus. The feedback from the mentor addressed that the teacher should not spend so much time on correcting learners' work and should devise other methods of correcting learners' work such as teaching learners to mark their own work or exchange books. The mentor AK revealed that the classroom visit and mentoring observations and post observation discussions enabled teachers to some extent to cover the syllabus:

I just tried to point out to the teachers ... how much time you spend the next day on going over homework because a lot of teachers spend the whole lesson going over the previous day's homework. So they never finish the syllabus. (Nel, 2015, p. 208)

\section{Conclusion}

The mentor did lesson observations which were received by the teachers in a positive way, where they experienced the mentor support and guidance as helpful and supportive. Through the lesson observations individual needs of teachers were picked up by the mentor and immediate support was provided during reflection sessions. The lesson observations also allowed for co-teaching between the teacher and the mentor which led to the development of both the teacher and the learners in the classroom. The exercise also enabled the mentor to identify the areas in mathematics where both the teachers and the learners needed more support. The teachers in the interviews acknowledged that through the process of co-teaching they gained insights into other ways of teaching certain topics as well as the appropriate instructional approaches that supported learners' knowledge acquisition. Another advantage of the mentor observing the teachers in the classroom was constructive feedback and reflection sessions that followed the lesson observation, which were quite informative and educational. The teachers' instructional and content needs identified during the lesson observation and co-teaching was also dealt with in the PD programmes that followed. Such activities allowed for need-based workshops customised to the specific needs of the participants on the programme.

Due to the presence of the mentor in the classroom, the mentor also established possible reasons why some of the teachers struggled to complete the syllabus. Remedial actions were implemented to address that challenge, both in class and in the workshops that followed. It can be safely concluded that both the teachers and the mentor benefited from the programme. It enabled them to identify the instructional and content gaps. The moving away from the teacher-centred approach to one where learners actively participate in class was a development process that was started through mentoring. Some of the teachers did develop by getting learners more actively involved in the classroom, but in general more can still be done to promote learner participation. More development is thus needed in this learner-centred instructional approach, keeping in mind that some teachers were exposed to earlier teacher training college methods which promoted passive learning. The provision of homework on a regular basis so as to ensure that concepts are scaffolded and errors are corrected timeously was another area where mentoring assisted and the teachers felt developed.

\section{Recommendations}

It can be recommended that PD programmes in South Africa include mentoring in their interventions to increase the effectiveness thereof. They must, however, take into account limited time for feedback after lesson observations as well as immediate feedback where possible straight after the lesson observation. Another recommendation is to try and ensure a match between the teachers and the mentor. The mentor should be able to form a good relationship with the teachers. This might possibly ensure a conducive environment for openness to trust and guidance. It can also be recommended that heads of departments be trained to act as mentors for their teams as mentoring is costly and time consuming. The heads of departments would be the most appropriate and effective mentor teachers as long as they are trained in the skills of mentorship and have the required content and 
instructional skills for the subject. Such an initiative will cut down on the cost of hiring and transporting a mentor teacher from another school. The head of department as a mentor teacher would also be able to offer school-based PD programmes that are contextualised to the teachers as well as the learners.

\section{Acknowledgements}

The first author thanks University of South Africa and the University of Johannesburg for the financial support for her PhD studies.

\section{Competing interests}

The authors declare that we have no financial or personal relationships that might have inappropriately influenced us in writing this article.

\section{Authors' contributions}

This was part of B.N.'s doctoral study where K.L. was the supervisor. B.N. did the initial conceptualisation of the manuscript, data analysis, interpretation, conclusion and writing. B.N. did further revisions to the conceptualisation of the manuscript, critical revision and interpretation of the data and final editing.

\section{References}

Adedeji, S.O., \& Alaniyan, O. (2011). Improving the conditions of teachers and teaching in rural schools across African countries. Addis Ababa: UNESCO IICBA.

Allen, T.D., Finkelstein, L.M., \& Poteet, M.L. (2009). Designing workplace mentoring programs: An evidence-based approach. Oxford: Blackwell-Wiley.

Ambrosetti, A., \& Dekkers, J. (2010). The interconnectedness of the roles of mentors and mentees in pre-service teacher education mentoring relationships. Australian Journal of Teacher Education, 35(6), 42-55. https://doi.org/10.14221/ajte. 2010v35n6.3

Aspfors, J., \& Fransson, G. (2015). Research on mentor education for mentors of newly qualified teachers: A qualitative meta-synthesis. Teaching and Teacher Education 48, 76-86. https://doi.org/10.1016/j.tate.2015.02.004

Babbie, E., \& Mouton, J. (2001). The practice of social research. Cape Town: Oxford University Press.

Badiali, B., \& Titus, N.E. (2010). Co-teaching: Enhancing student learning through mentor-intern partnerships. School-University Partnerships, 4(2), 74-80. Available from http://files.eric.ed.gov/fulltext/EJ969840.pdf

Best, J.W., \& Kahn, J.V. (1998). Research in education. (8th edn.). Boston, MA: Allyn \& Bacon Publishers.

Centre for Development and Enterprise. (2013). South Africa's education crisis: The quality of education in South Africa 1994-2011. Johannesburg: CDE.

Croft, A., Coggshall, J., Dolan, M., Powers, E., \& Killion, J. (2010). Job-embedded professional development: What it is, who is responsible, and how to get it done well. Issue Brief. Washington, DC: National Comprehensive Center for Teacher Quality. Available from http://files.eric.ed.gov/fulltext/ED520830.pdf

De Clercq, F., \& Phiri, R. (2013). The challenges of school-based teacher development initiatives in South Africa and the potential of cluster teaching. Perspectives in Education, 31(1), 77-86. Available from http://hdl.handle.net/11660/3648

De Kadt, D. (2010). Why human capital matters. Focus: The Journal of the Helen Suzman Foundation, 59, 3-9. Available from http://hsf.org.za/resource-centre/ focus/Focus59web.pdf

Department of Education. (2005). Report on the ministerial commission on rural education: A new vision for rural schooling. Pretoria: DOE. Available from http:// www.education.gov.za/Portals/0/Documents/Reports/Ministerial\%20Report\% 20on\%20Rural\%20Education.pdf?ver=2011-01-18-115532-587

Edwards, A. (1998). Mentoring student teachers in primary schools: Assisting student teachers to be learners. European Journal of Teacher Education, 21(1), 47-62. https://doi.org/10.1080/0261976980210106

Gall P.J., Gall, M.D., \& Walter, R.B. (1999). Applying educational research: A practical guide. (4th edn.). New York, NY: Longman.

Gardiner, M. (2008). Education in rural areas. Issues in Education Policy, Number 4 Johannesburg: Centre for Education Policy Development. Available from http:// www.cepd.org.za/files/CEPD_Issues_in_education_Education_in_rural_areas.pdf
Gordon, A. (2009). Restructuring teacher education. Issues in Education Policy, Number 6. Johannesburg: Centre for Education Policy Development. Available from http:// www.cepd.org.za/files/CEPD_Issues_in_education_Teacher_Education.pdf

Graven, M.H. (2014). Poverty, inequality and mathematics performance: The case of South Africa's post-apartheid context. ZDM: The International Journal on Mathematics Education, 46(7), 1039-1049. https://doi.org/10.1007/s11858-0130566-7

Grbich, C. (2006). Qualitative data analysis: An introduction. London:Sage.

Guskey, T.R. (2000). Evaluating professional development. Thousand Oaks, CA Corwin.

Harrison, C. (2005). Teachers developing assessment for learning: Mapping teacher change. Teacher Development, 9(2), 255-263. Available from http:// www-tandfonline-com.ez.sun.ac.za/doi/abs/10.1080/13664530500200251

Hatch, J.A. (2002). Doing qualitative research in education settings. New York, NY: SUNY Press.

Hattingh, A. (2009). Meester-wiskundeonderwysers as mentors in ondervoorsiene en benadeelde skole [Master mathematics teachers as mentors for underperforming and disadvantaged schools]. Suid-Afrikaanse Tydskrif vir Natuurwetenskap en Tegnologie, 28(4), 340-354. Available from http://satnt.ac.za/index.php/satnt/ Tegnologie, $28(4), 340-3$
article/viewFile/70/59

Human Sciences Research Council. (2005). Emerging voices: A report on education in South African rural communities. Cape Town: HSRC Press. Available from http:// www.hsrcpress.ac.za/product.php?productid $=1957$

Islam, F. (2012). Understanding pre-service teacher education discourses in communities of practice: A reflection from an intervention in rural South Africa. Perspectives in Education, 30(1), 19-29. Available from http://hdl.handle.net/10520/ EJC87665

Khosa, G. (2010). Sustainable school improvement: A partnership between the state the private sector and civil society. Johannesburg: JET Education Services.

Kilpatrick, J., Swafford, J., \& Findell, B. (Eds.). (2001). Adding it up: Helping children learn mathematics. Washington, DC: National Academy Press.

Krefting, L. (1991). Rigor in qualitative research: The assessment of trustworthiness. American Journal of Occupational Therapy, 45, 214-222. https://doi.org/10.5014/ ajot.45.3.214

Kriek, J., \& Grayson, D. (2009). A holistic professional development model for South African physical science teachers. South African Journal of Education, 29 185-203. Available from http://www.sajournalofeducation.co.za/index.php/saje/ article/viewFile/123Jeanne/149

Lietz, C.A., Langer, C.L., \& Furman, R. (2006). Establishing trustworthiness in qualitative research in social work. Qualitative Social Work, 5(4), 441-458. https://doi.org/ $10.1177 / 1473325006070288$

Luneta, K. (2006). Mentoring as professional development in mathematics education A teaching practicum perspective. Education as Change, 10(1), 17-25. https://doi. A teaching practicum perspective.
org $/ 10.1080 / 16823200609487126$

Luneta, K. (2012). Designing continuous professional development programmes for teachers: A literature review. African Education Review, 9(2), 360-379. https:// doi.org/10.1080/18146627.2012.722395

Makgato, M., \& Mji, A. (2006). Factors associated with high school learners' poor performance: A spotlight on mathematics and physical science. South African Journal of Education, 26(2), 253-266. Available from http://www. sajournalofeducation.co.za/index.php/saje/article/viewFile/80/55

Maree, K. (Ed.). (2011). First steps in research. (7th impression). Pretoria: Van Schaik Publications.

Masinire, A., Maringe, F., \& Nkambule, T. (2014). Education for rural development Embedding rural dimensions in initial teacher preparation. Perspectives in Education, 32(3), 146-158. Available from http://hdl.handle.net/10520/ EJC160055

McKay, S.L. (2010). Improving classroom teaching. English Teacher Talk, 39, 1-2. Available from https://www.cape.edu/docs/TTalk0039.pdf

McKinsey \& Company. (2007). How the world's best performing schools systems come out on top. Available from http://mckinseyonsociety.com/how-the-worlds-bestperforming-schools-come-out-on-top/

McLaughlin M.W., \& Talbert, J.E. (2006). Building school-based teacher learning communities: Professional strategies to improve student achievement. New York, NY: Teacher College Press.

Murray, A. (2010). Empowering teachers through professional development. English Teacher Forum, 48(1), 2-11. Available from https://americanenglish.state.gov/ files/ae/resource_files/10-48-1-b.pdf

Myall, M., Levett-Jones, T., \& Lathlean, J. (2008). Mentorship in contemporary practice: The experiences of nursing students and practice mentors. Journal of Clinical Nursing, 17, 1834-1842. https://doi.org/10.1111/j.1365-2702. 2007.02233.x

$\mathrm{Nel}$, B.P. (2015). An evaluation of a mathematics professional development teacher development programme. Unpublished doctoral dissertation. University of South Africa, Pretoria, South Africa. Available from http://hdl.handle.net/10500/19048

Onchwari, G., \& Keengwe, J. (2008). The impact of a mentor-coaching model on teacher professional development. Early Childhood Education Journal, 36, 19-24. https://doi.org/10.1007/s10643-007-0233-0

Reddy, V. (2006). Mathematics and science achievement at South African schools in TIMSS 2003. Cape Town: HSRC Press. Available from https://www.hsrcpress.ac.za/ product. . php ?cat $=26 \&$ browse $=m \&$ productid $=2148 \&$ freedownload $=1 \& \mathrm{js}=n$

Rhodes, C., Stokes, M., \& Hampton, G. (2004). A practical guide to mentoring, coaching and peer-networking. London: Routledge Falmer. 
Santamaria, L.J. (2009). Culturally responsive differentiated instruction: Narrowing gaps between best pedagogical practices benefiting all learners. Teachers College Record, 111(1), 214-247. Available from http://www.tcrecord.org/Content.asp? Contentld $=15210$

Schoenfeld, A.H., \& Floden, R.E. (2014). An introduction to the TRU Math Dimensions. Berkeley, CA: Graduate School of Education, University of California, Berkeley \& East Lansing, MI: College of Education, Michigan State University. Available from http://ats.berkeley.edu/tools/TRUMathDimensionsAlpha.pdf

Shulman, J.H., \& Sato, M. (2006). Mentoring teachers towards excellence: Supporting and developing highly qualified teachers. San Francisco, CA: Jossey-Bass.

Sibanda, D., \& Jawahar, K. (2012). Exploring the impact of mentoring, in-service teachers enrolled in a mathematics, science and technology education programme. Alternation, 19(2), 259-272. Available from http://alternation.ukzn ac.za/Files/docs/19.2/13\%20Sib.pdf
Stein, M.K., Engle, R.A., Smith, M.S., \& Hughes, E.K. (2008). Orchestrating productive mathematical discussions: Five practices for helping teachers move math thathematical Thinking and learning, 10,313-340. https:/doi.org/ 10.1080/10986060802229675

Sullivan, P. (2011). Teaching mathematics: Using research-informed strategies. Australian Education Review, 59. Melbourne: Australian Council for Education Research. Available from http://research.acer.edu.au/aer/13/

Venkat, H., \& Spaull, N. (2015). What do we know about primary teachers' mathematical content knowledge in South Africa? An analysis of SACMEQ 2007 International Journal of Educational Development, 41, 121-130. https://doi. org/10.1016/j.ijedudev.2015.02.002

Yin, R.K. (1984). Case study research: Design and methods. Newbury Park, CA: Sage.

Zikmund, W.G. (2003). Health economics research method 2003/2. Available from http://pioneer.netserv.chula.ac.th/ ppongsa/2900600/LMRM02.pdf 